\title{
Seasonal Analysis of Atmospheric Changes in Hudson Bay during 1998-2018
}

\author{
Farahnaz Fazel-Rastgar (1) \\ York University, Toronto, Canada \\ Email: ffazelrastgar@gmail.com
}

How to cite this paper: Fazel-Rastgar, F. (2020). Seasonal Analysis of Atmospheric Changes in Hudson Bay during 1998-2018. American Journal of Climate Change, 9, 100-122.

https://doi.org/10.4236/ajcc.2020.92008

Received: April 2, 2020

Accepted: May 12, 2020

Published: May 15, 2020

Copyright $\odot 2020$ by author(s) and Scientific Research Publishing Inc. This work is licensed under the Creative Commons Attribution International License (CC BY 4.0).

http://creativecommons.org/licenses/by/4.0/

\begin{abstract}
The main objective of this study is to examine the NARR (North American Regional Reanalysis Model) high-resolution dataset to understand the last two decades dramatic climate changes in Hudson Bay associated with the atmospheric keys by synoptically analysis. The anomalies of the near-surface meteorological parameters such as air temperature, humidity, mean sea level pressure, wind vectors along with cloudiness, precipitation, surface albedo and downward longwave radiation at surface in seasonally based changes have been analysed. The increase in low-level thermal structure leads to changing the near-surface humidity, evaporation, cloudiness, precipitation and downward longwave radiation at the surface. Also, winds have been accelerated associated with anticyclonic curvature development. The results show significant atmospheric changes during the last two decades in Hudson Bay with the highest values mostly during winter and fall seasons in the north, east boundaries and James Bay area. Using the statistical analysis for mean low-level temperature, surface albedo, low-level clouds and evaporation at the surface during nearly recent 2 decades (1998-2018) rather than the normal climatology mean (1981-2010) have revealed the meaningful significant difference for mentioned parameters. The statistical analysis results show that during spring there is a significant positive correlation between low clouds anomaly and $2 \mathrm{~m}$ air temperature anomaly rather than other seasons. So, the recent atmospheric changes in the study area as a region located in the Arctic and sub-Arctic can contribute to extra-local and global warming.
\end{abstract}

\section{Keywords}

Climate Change, Sea Surface Temperature, Clouds, NARR Model, Hudson Bay

\section{Introduction}

The climate of Arctic has changed significantly during the past three decades (Deser \& Teng, 2008; Serreze et al., 2007). Due to greenhouse gases emissions, 
the global mean temperature raised by $0.2^{\circ} \mathrm{C}$ decade $^{-1}$ from 1970 (Hansen et al. 2006). The volume of sea ice in the Arctic has reduced by $75 \%$ from the 1980 s (Schweiger et al., 2011; Overland \& Wang, 2013; Overland et al., 2014). Arctic warming is twice fast in comparison to the global average (Blunden \& Arndt 2012). Arctic sea ice decreasing is the most affected factor due to Arctic warming. The surface albedo is controlled by the melting of ice and it is one of the significant factors causing Arctic amplification (Serreze \& Francis, 2006; Screen, Simmonds, \& Keay, 2011; Serreze \& Barry, 2011). The concept of the Arctic amplification firstly was anticipated from model simulation starting 1980 (Manabe \& Stouffer, 1980; Holland \& Bitz, 2003). Albedo feedback is one of the key factors to describe the faster loss of sea ice and low-level atmospheric warming (Flanner et al., 2011; Serreze \& Barry, 2011). Albedo feedback is very considerable during summertime when there is less Arctic sea ice along with the highest solar radiation (Comiso et al., 2008). The important significant issue for Arctic amplification is marked by seasonality changes when the winter warming beats summer warming by nearly at a factor of 4 (Bintanja \& van der Linden, 2013). Also, a recent study shows the possible linkage of recent summer heatwave of 2019 in Canadian Arctic to the Arctic sea ice decline of summer 2019 (Fazel-Rastgar, in press a). In addition, the synoptic climatological analysis of the three recent summer heatwaves of 2007, 2012 and 2016 in the Canadian Arctic has been investigated by Fazel-Rastgar (in press b). Recent studies demonstrate that the Arctic September sea-ice coverage decreasing has been accelerating from 1996 (Ogi \& Rigor, 2013). The winter Arctic warming is significant for example during the month of December, whereas the Arctic experiences slight warming during summertime (Bintanja \& Krikken, 2016). Arctic surface warming is very strong during most of the months in the year and it is mostly persistent with sea ice extent decline (Screen, Simmonds, \& Keay, 2011). There are different atmospheric factors which are affected by Arctic warming such as humidity, cloud cover, precipitation and winds. For example, there is a positive response of the clouds cover to sea ice decline during fall (Kay \& Gettelman, 2009). The mean Arctic precipitation is anticipated to have an increase much greater than the global value (Bintanja \& Andry, 2017; Bintanja \& Selten, 2014) in the recent century. This is because of the sea ice melting, makes more open water and then to increase more evaporation (Bintanja \& Selten, 2014). The variation of the cloud cover in the Arctic can be described by the atmospheric thermal and moisture structure and then any increase in near-surface temperatures can link to the sea ice decline. Clouds have important and multifaceted role in radiative energy transmission associated with different variables such as microphysical properties, height, area fraction, the profiles of temperature and the structure of surface (Schweiger, 2004). The consequent of the static stability reduction and increase of the vertical motion along with an increase the low-level humidity can contribute to the more atmospheric cloudiness. For example, the recent climate change study in Baffin Island as a part of the Canadian Arctic has revealed that an increase in near surface air temperature can be connected to the positive ver- 
tical motion anomalies (Fazel-Rastgar, 2020).

So, it is important to understand the seasonal based of low-level atmospheric changes in Arctic regions which can be linked to cloud development. For example, the cloud formation during fall and spring is correlated positively with the temperature of the surface (Eastman \& Warren, 2010). Cloud observation by satellite from 1982 to 1999 displays rather warm and cloudier Arctic in spring and summer seasons whereas rather cool and less cloudy during winter (Wang \& Key, 2003).

\section{Hudson Bay}

Hudson Bay is the largest inland sea in the world which extends between 51 and 63 degrees north latitude. It is in the Canadian Arctic and Sub-Arctic areas. Hudson Bay marks with different climatic conditions in the west, north, east and south. The changes in the sea ice cover record in Hudson Bay can be evidence of global climate change (Chapman \& Walsh, 1993; Parkinson 2000a, 2000b; Jeffers et al., 2001; Parkinson \& Cavaliere, 2002; Gough et al., 2004). By using the passive-microwave data from satellite observation, the sea-ice extents have been calculated for a periodic time from 1979 to 1999 over Hudson Bay, Foxe Basin and Hudson Strait (Parkinson \& Cavaliere, 2002). The results of this study have revealed that during the 21-year study period the yearly-average of sea ice extent with over $15 \%$ coverage was calculated $798,000 \mathrm{~km}^{2}$ which has decreased with a trend of $-4300 \pm 1400 \mathrm{~km}^{2} \cdot \mathrm{a}^{-1}$ (99\% CI; $p=0.01$ ) mostly in north-west and southern parts. The open-water period due to Hudson Bay sea ice reduction, has been increased about three weeks in comparison to the 1990s (Hochheim \& Barber, 2010). The ice cover has been decreasing during June and July and in November and December. This indicates the earlier melting in fall along with late formation during fall (Parkinson \& Cavaliere, 2002).

\section{Methodology and Data Collection}

This study investigates to understand the last two decades (1998-2018) dramatic seasonal climatic changes in Hudson Bay associated with the atmospheric key factor changing analysis. This work examines the NARR (The North American Regional Reanalysis Model) data in Hudson Bay area. The NARR model (Mesinger et al., 2006) uses a very high-resolution NCEP (National Centers for Environmental Prediction) Eta Model with a grid resolution of nearly at $0.3 \times 0.3$ degrees or $32 \mathrm{~km}$ at the lowest latitude along with the Regional Data Assimilation System (RDAS) which significantly can assimilate the precipitation along with other variables. The advances in the model and assimilation have resulted in a dataset with important improvements in the accuracy of winds, temperature and precipitation in comparison with NCEP-DOE Global Reanalysis 2. The NARR model outputs include 8 times daily data in 29 vertical level. The NARR dataset is available from 1979 for 8-times daily, for $0 \mathrm{Z}, 3 \mathrm{Z}, 6 \mathrm{Z}, 9 \mathrm{Z}, 12 \mathrm{Z}, 15 \mathrm{Z}$, $18 \mathrm{Z}$ and $21 \mathrm{Z}$ (0000 Universal Time Coordinate). The monthly data set of NCEP (Kalnay et al., 1996) is available since 1948. Here, the available historical archived model dataset has been used to analyse the mean values, finding general 
patterns along with the abnormal or anomaly patterns. Then by the study shifts and departures from normal period (climatological mean values from 1981 to 2010) as a base to follow the World Meteorological Organization (WMO) Policy, which recommends using the latest 30-year average. Anomalies can designate the climate variability and make it possible to understand the changes and the abnormal patterns on the regional scale using the high-resolution NARR dataset. Also, the anomalies present a frame of reference which allows for meaningful calculations and more accurate trends. This work also applies the statistical analysis like t-tests for 2 meter air temperatures, 10 meter winds speed and accumulated evaporation at surface along with the surface albedo for anomaly values during 1998-2015 for other seasonal periods (spring, summer and fall) to examine for an existence of a significant difference between anomaly period and climatology normal periodic time for mentioned parameters over Hudson Bay. In this stage, at first the multiple dimension NetCDF data set for all each seasons from NARR website (https://www.esrl.noaa.gov/psd/) have been downloaded. Then, the acquire Hudson Bay shapefile for the coastal boundary ArcGIS from Canadian census website

(http://www12.statcan.gc.ca/census-recensement/2011/geo/bound-limit/bound-1 imit-2011-eng.cfm) have been extracted. Then the extract data for latitude and longitude Hudson Bay shapefile also has been extracted and in the next step, data from both Hudson Bay shapefile for the coastal boundary ArcGIS and NetCDF data set have been combined. Finally, the resulted data have been spread to the excel files for another subsequent analysis.

\section{Results and Discussions}

\subsection{Yearly and Seasonal Sea Surface Temperature}

Figure 1 shows a time series of the yearly mean sea surface temperature (SST) in Hudson Bay area from 1948 to 2018. This displays a recent shift in SST in Hudson Bay starting from 1998.Also, seasonal mean SST for winter, spring, summer and fall time series also show this shift with the highest slope during winter and

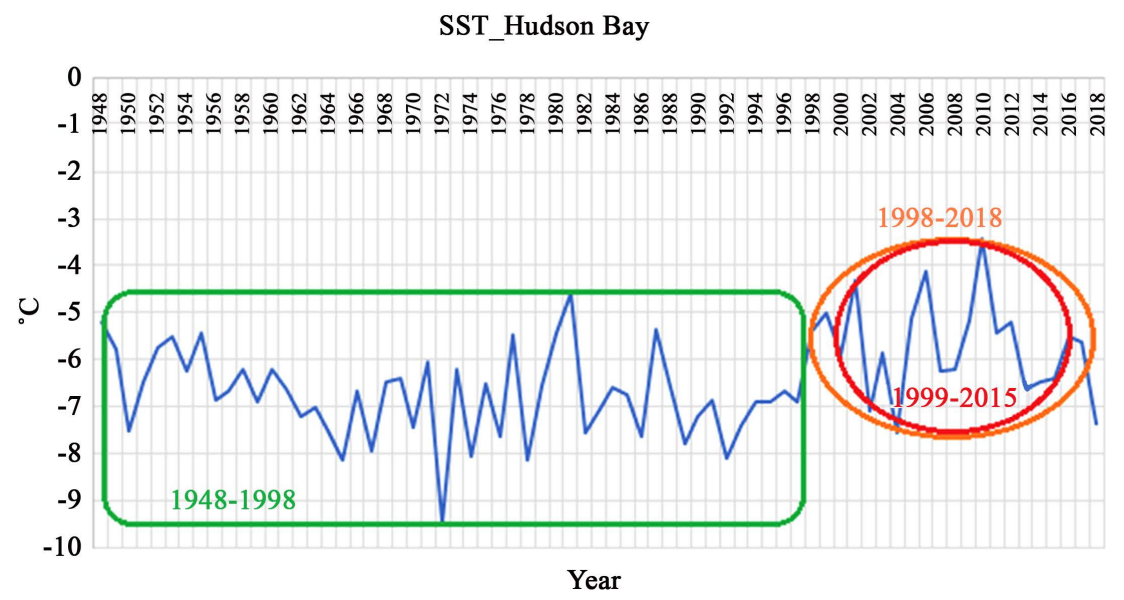

Figure 1. Yearly mean SST time series for Hudson Bay from 1948 to 2018. 
the lowest slope during spring (Figure 2). The sub anomaly period (1999-2015) from the recent 2 decades has been selected for statistical analysis which is presented in the Section 17.

Figure 3 shows sea surface temperature (SST) anomaly map during 1998-2018 (study period) departure from 1981-2010 (normal period) for winter (a), spring (b), summer (c) and fall (d) in Hudson Bay region. The sea surface temperatures have been increased in Hudson Bay. During winter, the highest value is $\sim 2.5 \mathrm{~K}$ in the north and northeast. In spring the maximum change in SST is in the north part around $1 \mathrm{~K}$. During summer the areas in the west have been getting warm with a maximum value around $1.1 \mathrm{~K}$. During fall, the SST has been increased in the west, east and north with the maximum around $1.9 \mathrm{~K}$.

\subsubsection{Air Temperature Anomaly at $2 \mathrm{~m}$}

Figure 4(a) shows $2 \mathrm{~m}$ air temperature anomaly in Hudson Bay region for the study period. This figure shows the increase of $2 \mathrm{~m}$ air temperature in all parts of Hudson Bay. The temperature anomaly increases from the west (around $1 \mathrm{~K}$ ) to the north-west, east and south-east. The increase in $2 \mathrm{~m}$ air temperature in the boundary region in the north, east and south boundaries is remarkable with the maximum value at around $4 \mathrm{~K}$. Figure 4 (b) shows $2 \mathrm{~m}$ air temperature anomaly during spring. The temperature at $2 \mathrm{~m}$ has been increased mostly in all part from $\sim 0.2 \mathrm{~K}$ to $\sim 1.8 \mathrm{~K}$ except the south-west part with no change. Figure 4 (c) shows the same map but for summer anomaly. During summer, Hudson Bay (except in

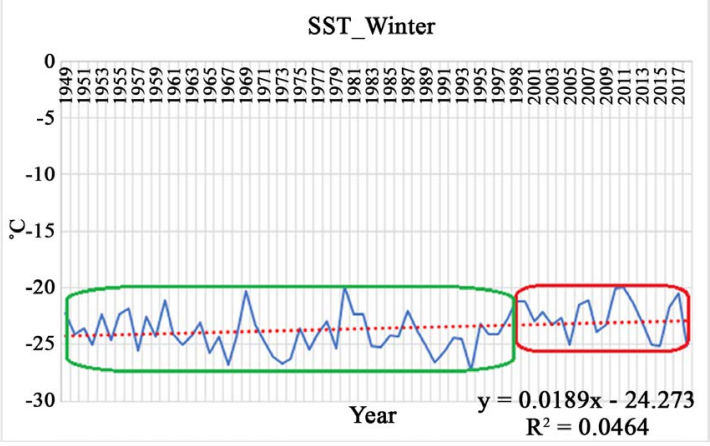

(a)

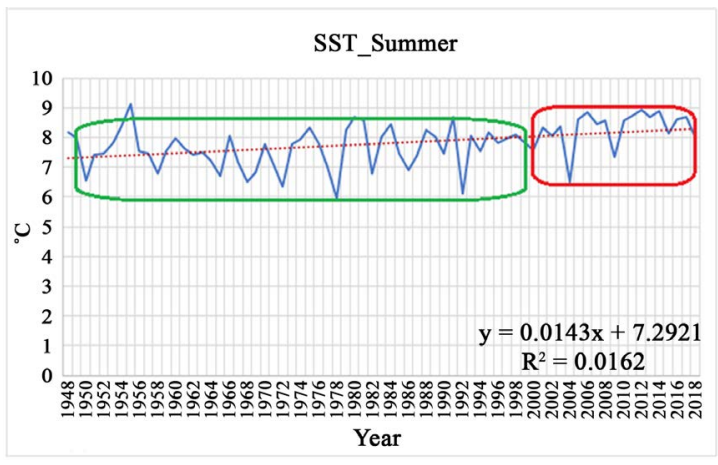

(c)

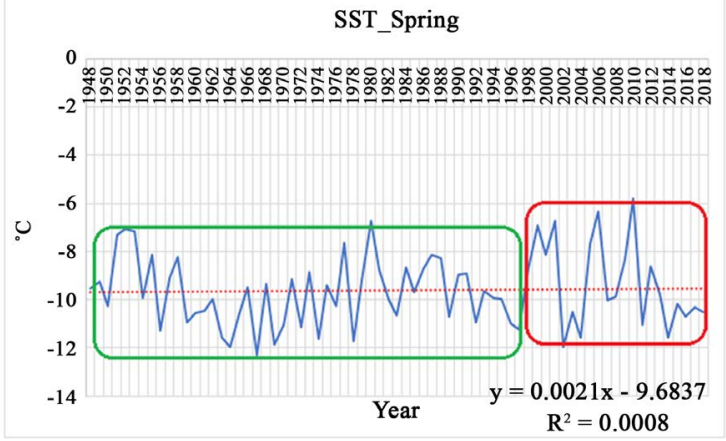

(b)

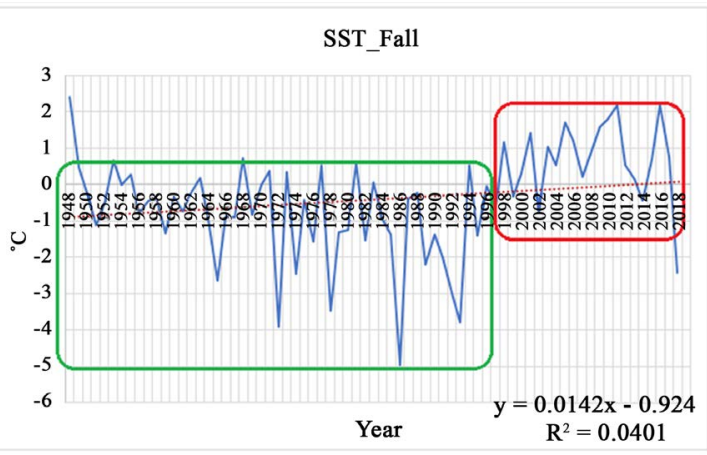

(d)

Figure 2. Seasonal mean time series of SST for winter (a); spring (b); summer (c) and fall (d) for Hudson Bay from 1948 to 2018. 


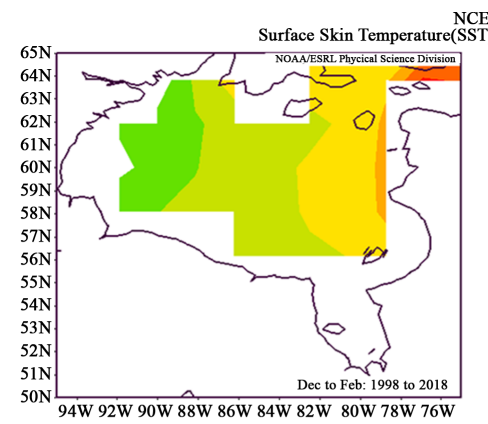

NCEP/NCAR Reanalysis
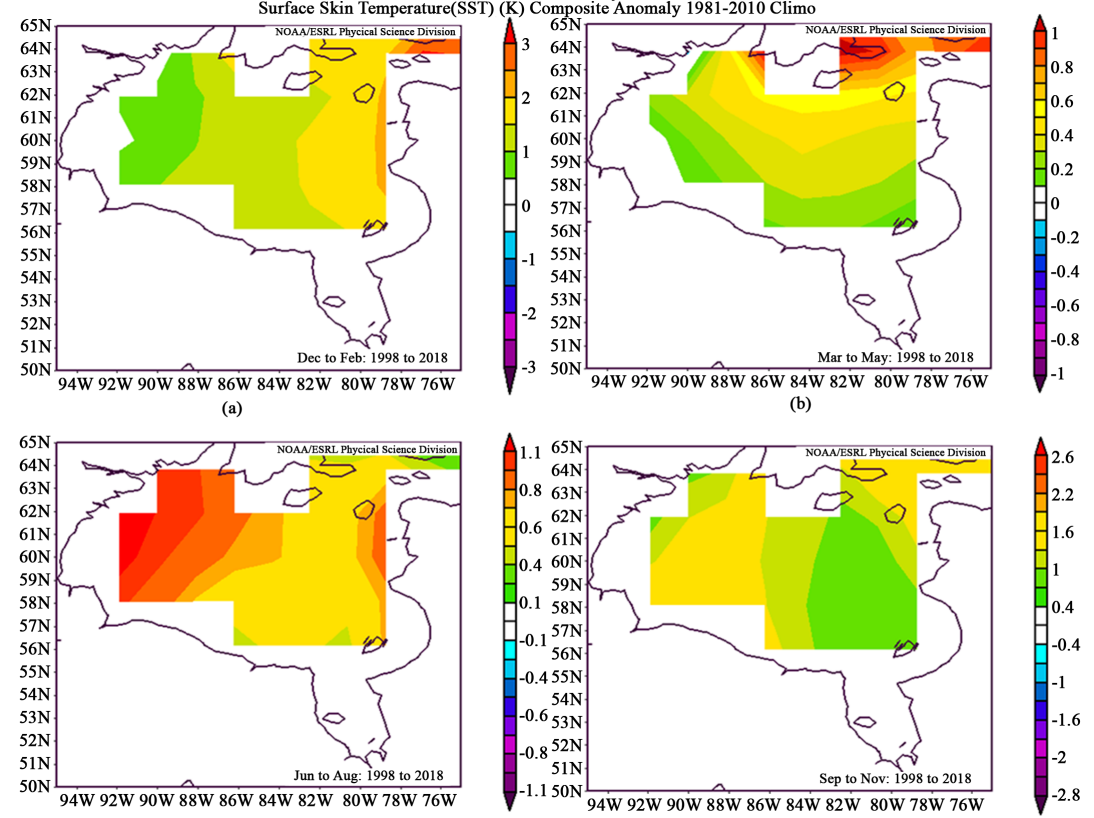

(c)

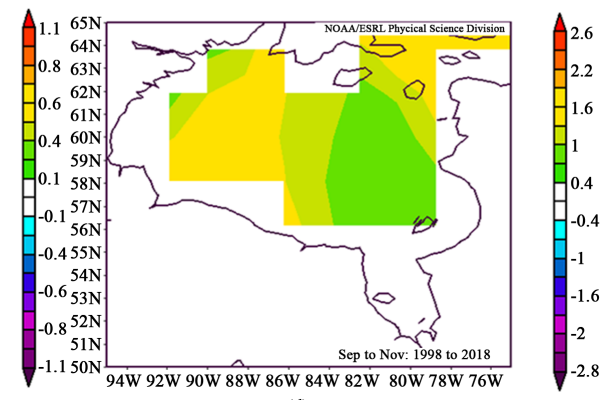

(d)

Figure 3. Seasonal SST anomaly map from 1998 to 2018 departure from 1981-2010 (normal period) for winter (a); spring (b); summer (c) and fall (d) for Hudson Bay.

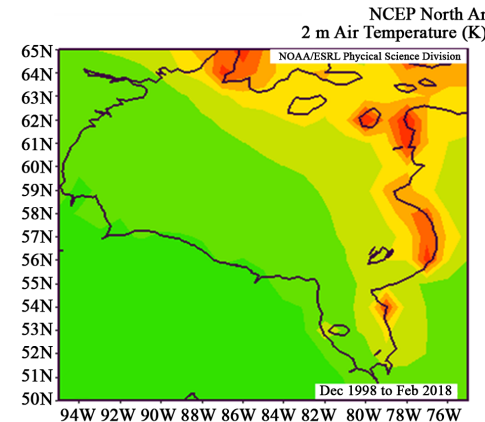

(a)

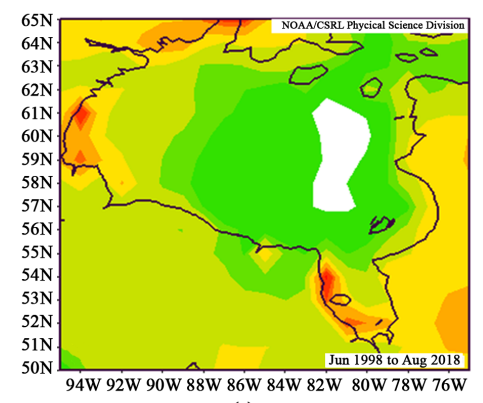

(c)

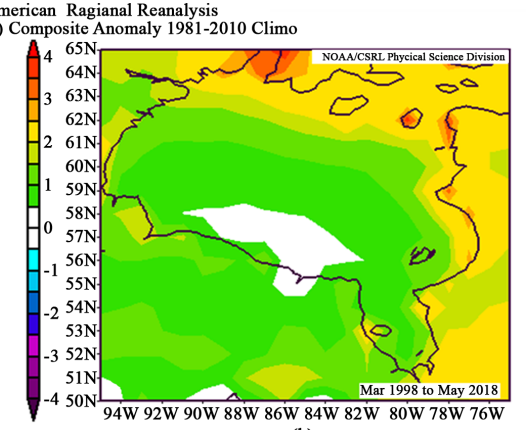

(b)

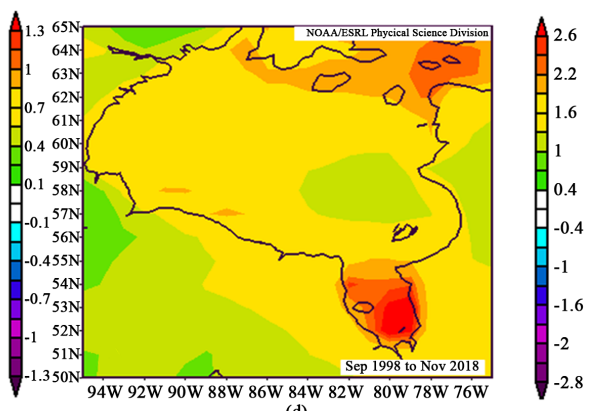

(d)

Figure 4. Seasonal anomaly map for $2 \mathrm{~m}$ air temperature from 1998-2018, departure from normal period for winter (a); spring (b); summer (c) and fall (d) for Hudson Bay.

a small area) has been getting warm from $\sim 0.1-1.2 \mathrm{~K}$. Figure 4 (d) shows that temperature at $2 \mathrm{~m}$ has been increased in the Hudson Bay in all parts from $\sim 1 \mathrm{~K}$ in the central part to $\sim 2 \mathrm{~K}$ in most of the area and the maximum value is in the James Bay area $\sim 2.6 \mathrm{~K}$. 


\subsubsection{Dew Point Air Temperature at $2 \mathrm{~m}$}

Wintertime dew point temperature at $2 \mathrm{~m}$ has been increased in the Hudson Bay region in all parts (Figure 5(a)). Dew point temperature is the temperature to which air must be cooled to reach saturation (assuming air pressure and moisture content are constant). A higher dew point means that more moisture is present in the air. The dew point temperature anomaly has been increased from west (around $0.5 \mathrm{~K}$ ) to the north-west and east with the maximum at around 4 $\mathrm{K}$. Spring dew point temperature at $2 \mathrm{~m}$ (Figure 5(b)) has been increased in the Hudson Bay region nearly in all parts of Hudson Bay. The temperature anomaly increases from the south (around $0.2 \mathrm{~K}$ ) to the north-west (maximum $\sim 1.8 \mathrm{~K}$ ). Figure 5(c) shows the dew point temperature at $2 \mathrm{~m}$ during summer anomaly study period. The pattern of dew point temperature at $2 \mathrm{~m}$ is like the $2 \mathrm{~m}$ air temperature anomaly which has been increased in the Hudson Bay region. The pattern of fall anomaly dew point temperature at $2 \mathrm{~m}$ (Figure 5(d)) is like Figure 4(d). Dew point temperature at $2 \mathrm{~m}$ has been increased nearly in all parts of Hudson Bay with the highest values at around $2.2 \mathrm{~K}$ in the north and James Bay region.

\subsubsection{Specific Humidity Anomaly at $2 \mathrm{~m}$}

Figure 6(a) shows an increase of specific humidity at $2 \mathrm{~m}$ from west to east in Hudson Bay during the winter season. The maximum values are mostly in the north-west at maximum around $0.00016 \mathrm{Kg} / \mathrm{Kg}$, in the east at maximum around $0.00026 \mathrm{Kg} / \mathrm{Kg}$ and south-east part and James Bay (which are in the area with

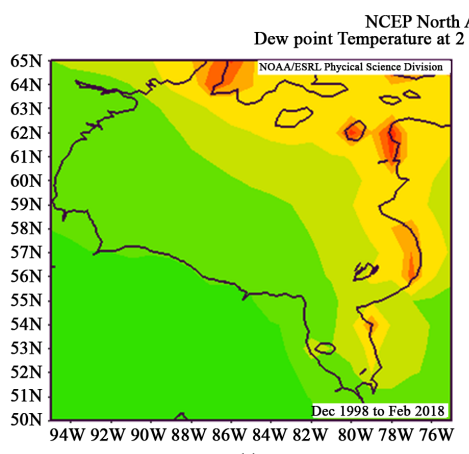

(a)

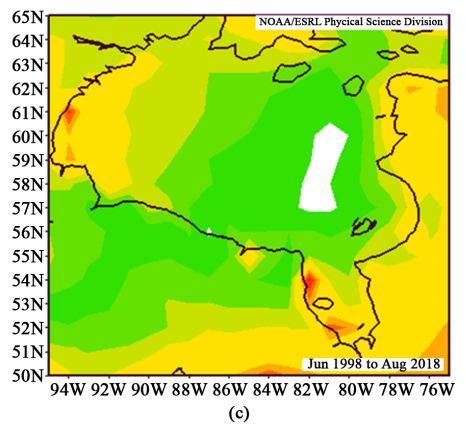

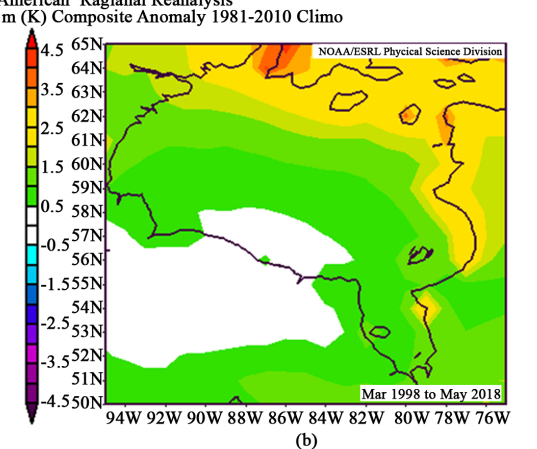

(b)

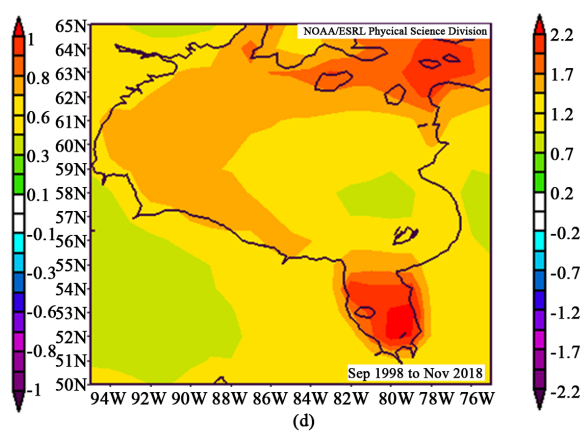

Figure 5. Seasonal anomaly map for $2 \mathrm{~m}$ dew point temperature from 1998-2018, departure from normal period for winter (a); spring (b); summer (c) and fall (d) for Hudson Bay. 


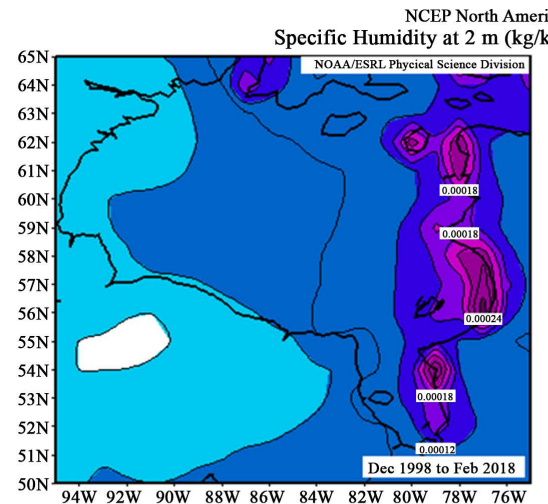

(a)

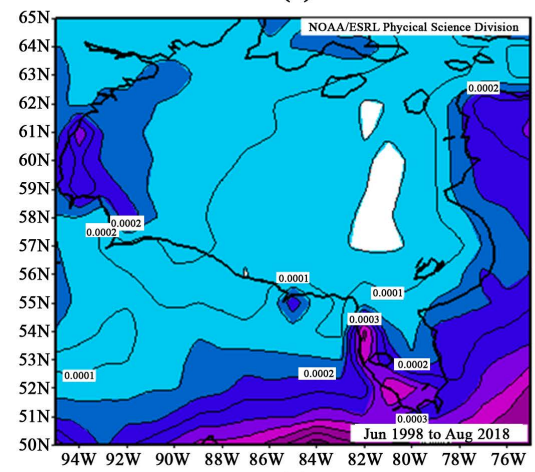

(c)

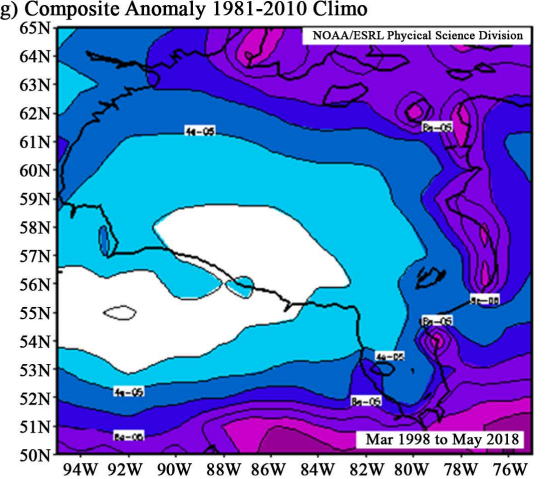

(b)

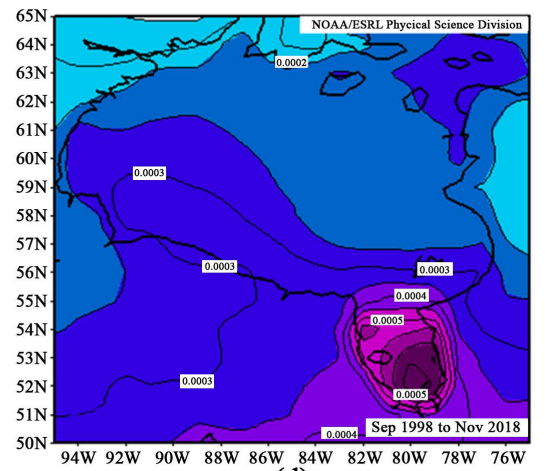

(d)

Figure 6. Seasonal anomaly map for specific humidity at $2 \mathrm{~m}$ from 1998-2018, departure from normal period for winter (a); spring (b); summer (c) and fall (d) for Hudson Bay.

rather higher $2 \mathrm{~m}$ air and dew point temperatures). Figure 6(b) shows an increase of specific humidity at $2 \mathrm{~m}$ during spring anomaly time in all parts except in small part as figure shows. The maximum values are mostly in the east and south-east of James Bay at around $0.00012 \mathrm{Kg} / \mathrm{Kg}$ (which are in the area with rather higher $2 \mathrm{~m}$ air and dew point temperatures). Figure 6(c) shows the increase of specific humidity at $2 \mathrm{~m}$ during summer time in Hudson Bay changing from $0.0001 \mathrm{~kg} / \mathrm{kg}$ (except small area with on change) to 0.0004 in the west and southern boundary of James Bay area, which shows more moisture is fed to the atmosphere near the surface in these areas. Figure 6(d) shows the increase of specific humidity at $2 \mathrm{~m}$ in all parts of Hudson Bay during fall anomaly season. This is specifying in increasing from north to the south in the James Bay area. The maximum value is in the James Bay area at around $0.0008 \mathrm{~kg} / \mathrm{kg}$ (which is in the area with rather higher $2 \mathrm{~m}$ air and dew point temperatures). The increase in $2 \mathrm{~m}$ specific humidity shows more moisture has been fed to the atmosphere near the surface during anomaly periodic time which making rather wet and warmer low-level atmosphere in the Hudson Bay region during fall, winter, summer and spring respectively.

\subsubsection{Relative Humidity Anomaly at $2 \mathrm{~m}$}

Figure 7(a) shows an increase of the air relative humidity (\%) at $2 \mathrm{~m}$ in all parts of Hudson during winter anomaly season. The relative humidity has been 


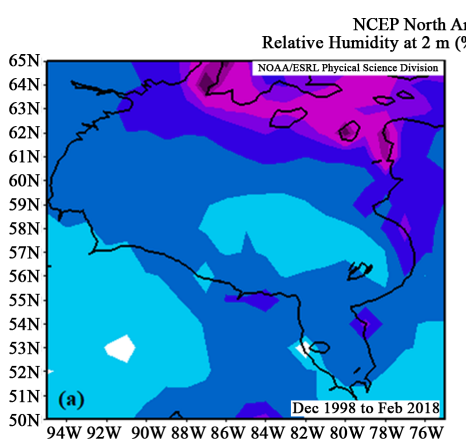

(a)

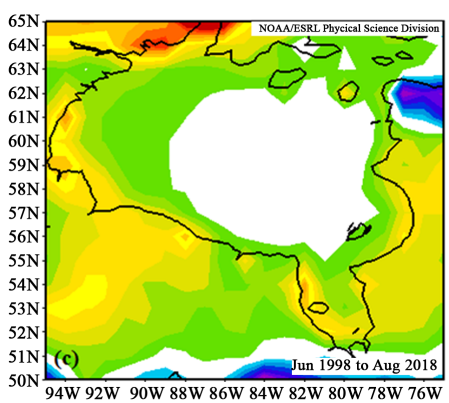

(c)

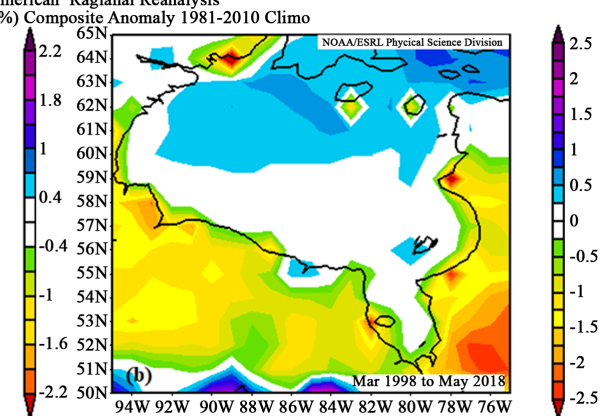

(b)

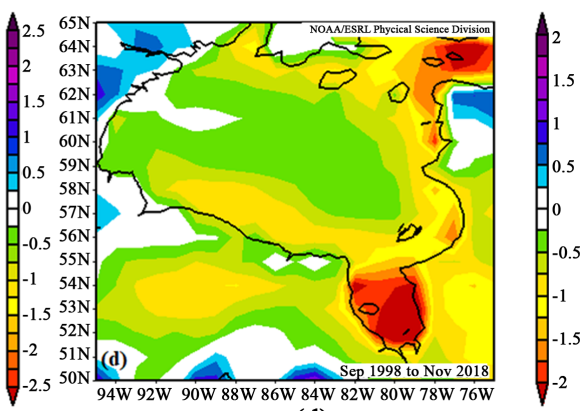

(d)

Figure 7. Seasonal anomaly map for relative humidity at $2 \mathrm{~m}$ from 1998-2018, departure from normal period for winter (a); spring (b); summer (c) and fall (d) for Hudson Bay.

increased from $0.4 \%$ in the center part to the maximum value around $2.2 \%$ in the northern part. Figure 7(b) shows the spring anomaly of the air relative humidity in the Hudson Bay during the study period. The relative humidity has been increased at around $1 \%$ in a maximum value in the northern part of Hudson Bay. In the other parts, there is no change, whereas in west, south and east boundaries the relative humidity has been decreased around 1\%. Figure 7 (c) shows the decrease $(\sim 0.25 \%-2 \%)$ in summer anomaly of the relative humidity in all parts with the maximum $2.5 \%$ in the north-west associated with rather higher temperature. Figure 7 (d) shows decreasing of air relative humidity in the Hudson Bay mostly in the northern, eastern and south-west and southern boundaries. The fall anomaly of the relative humidity has been decreased from $0.25 \%$ to the maximum value around $2 \%$ in the James Bay area as can be seen in Figure 7 (d). The decrease in relative humidity is associated with rather higher temperature. Also, the relative humidity is, in fact, greater in wintertime rather than in the summertime, because the cold air does not need as much moisture which is saturated as warmer air.

\subsection{Accumulated Evaporation Anomaly at Surface}

Figure 8(a) and Figure 8(b) show the increasing of accumulated evaporation at surface mostly during winter (with a maximum $\sim 0.14 \mathrm{~kg} \cdot \mathrm{m}^{-2}$ ) and spring anomaly time (with a maximum $\sim 0.04 \mathrm{~kg} \cdot \mathrm{m}^{-2}$ ) in some parts around the northeast, east and east of James Bay. As Figure 8(c) shows there is no change in accumulated evaporation at the surface during summer anomaly time. Figure 8(d) 


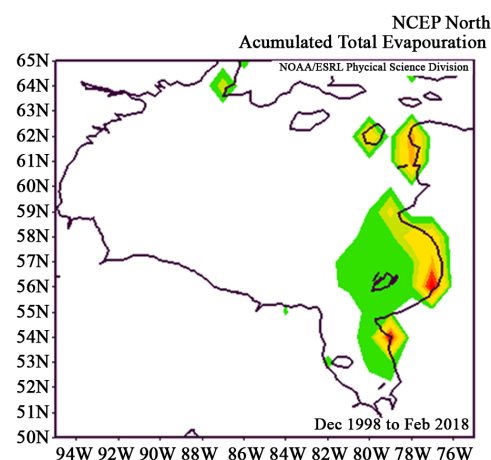

(a)

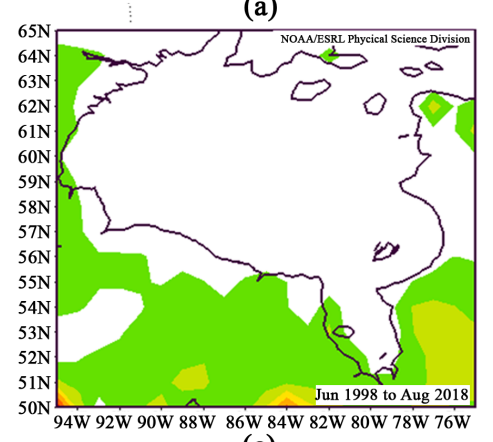

(c)

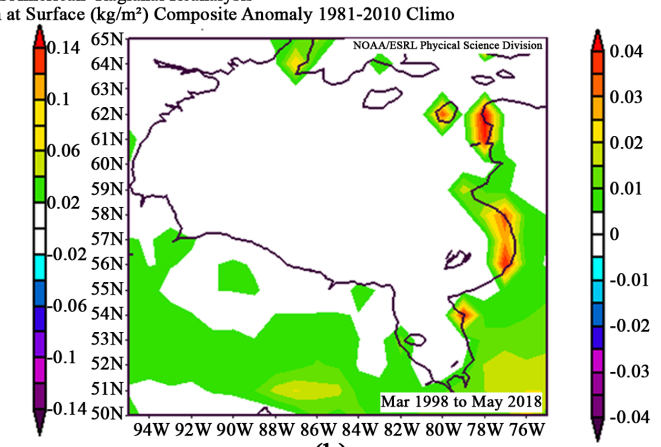

(b)

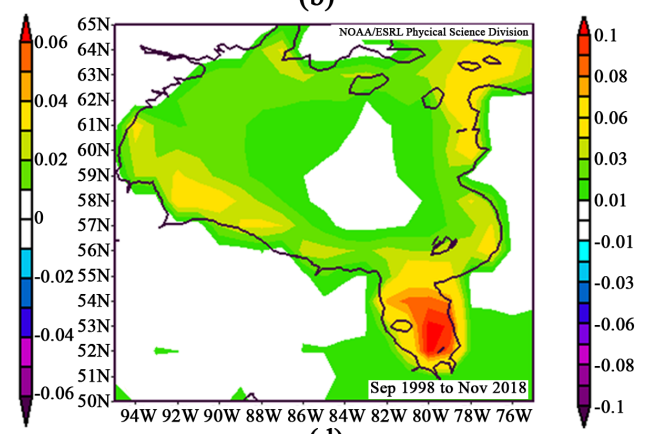

(d)

Figure 8. Seasonal anomaly map for accumulated evaporation at surface from 1998-2018, departure from normal period for winter (a); spring (b); summer (c) and fall (d) for Hudson Bay.

shows the increasing of accumulated evaporation at the surface during fall anomaly season mostly in all parts (except in the central part of Hudson Bay) from $\sim 0.01 \mathrm{~kg} \cdot \mathrm{m}^{-2}$ to a maximum value $\sim 0.1 \mathrm{~kg} \cdot \mathrm{m}^{-2}$ in James Bay region. These results show that during fall, with the existence of more moisture availability near the surface along with the rather warmer air temperatures, the evaporation also has been increased. This means that more water vapour has been fed to the low-level atmosphere during the anomaly period over the area with rather higher increase in temperature. During summer the atmospheric relative humidity controls the evaporation, and the small value in the decreased relative humidity is the biggest single factor which can reduce the precipitation efficiency (Ye et al., 2014).

\subsubsection{High Cloud Area Fraction Anomaly}

Figure 9(a) shows that during winter anomaly time the high cloud area fraction has been increased $(0.15 \%-1.5 \%)$ in Hudson Bay mostly in the west, east, centre and James Bay area whereas it has been decreased in the north part. Figure 8(b) is the same map as Figure 9(a) but for spring anomaly period. This figure shows that high cloud area fraction has been increased in James Bay $(\sim 0.3 \%-1.8 \%)$. Whereas the large central areas have fractional decreasing of high cloud cover $(\sim 0.3 \%-1.2 \%)$. Figure 9(c) shows the same as Figure 9(a) but for summer anomaly time. The high-level clouds area fraction has been increased in most parts of Hudson Bay except in the central and north parts. The pattern shows that the increase of high clouds in the southern part with the maximum $~ 2.5 \%$ 


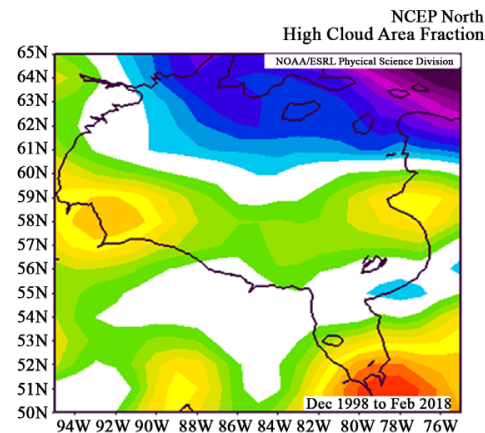

(a)

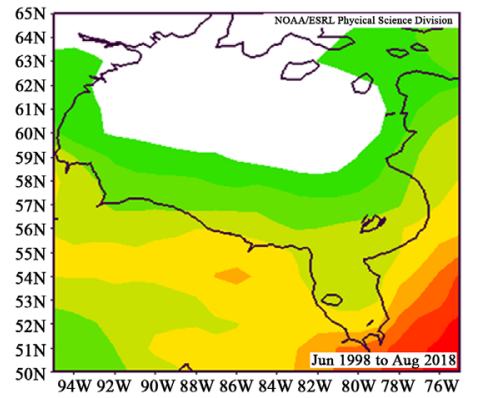

(c)

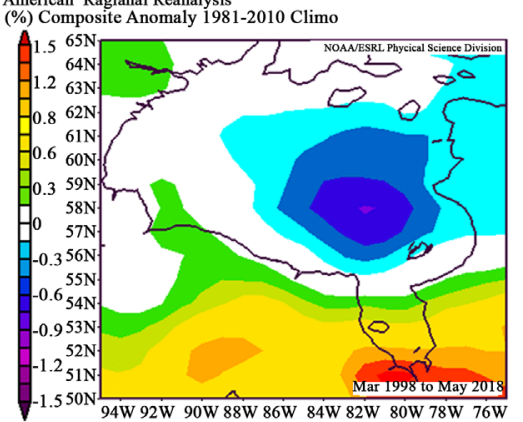

(b)

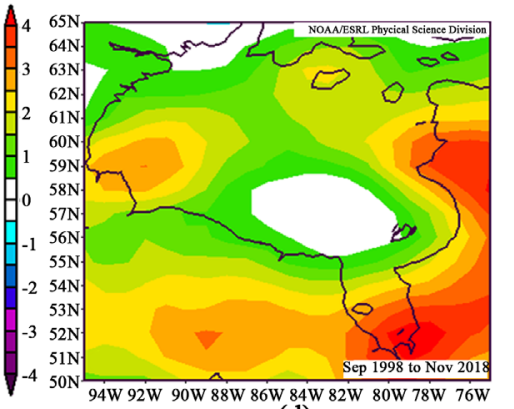

(d)
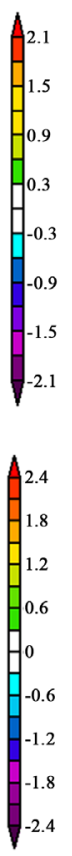

Figure 9. Seasonal anomaly map for high cloud area fraction from 1998-2018, departure from normal period for winter (a); spring (b); summer (c) and fall (d) for Hudson Bay.

in the James Bay area. The increase of high cloud cover over the Arctic areas during summer can be linked to the less sea ice during the next season. Figure 8 (d) shows the fall anomaly high cloud area fraction. The high cloud area fraction has been increased in most parts of Hudson Bay with the maximum value in the south part of James Bay around 2.4\%. The fall cloud increasing may cause to delay in ice freezing and then cause to form rather thinner ice during the cold seasons. The cloud formation during fall and spring is correlated positively with the temperature of the surface (Eastman \& Warren, 2010).

\subsubsection{Low Cloud Area Fraction Anomaly}

Figure 10(a) shows the winter anomaly of the low cloud area fraction. The low cloud area fraction has been decreased in most parts of Hudson Bay whereas in some small areas in the northeast it has been increased. Over the north part, there is no change. Figure 10(b) shows the Hudson Bay low cloud area fraction during spring anomaly study time. The low-level cloud area fraction has been decreased in most parts of Hudson Bay whereas in some small areas in the north, northeast, east and east of James Bay boundaries it has been increased. It can be the result of small locally and shallow atmospheric instability. Figure 10 (c) shows the low cloud area fraction anomaly during summer with an increasing pattern in most parts of Hudson Bay in the centre, north and north-west $(\sim 0.25 \%-\sim 1.25 \%)$ and from south-east to the east $(\sim 0.25 \%-\sim 2 \%)$. Figure 10(d) shows the low cloud area fraction during fall anomaly season over the study area. The low-level cloud area fraction has been increased in some parts in the centre, south, north-west, west and the northeast form $0.5-4 \%$, 


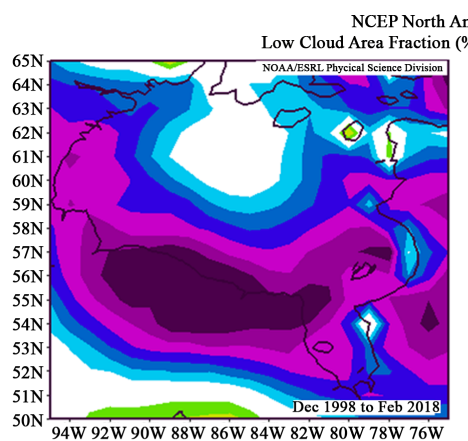

(a)

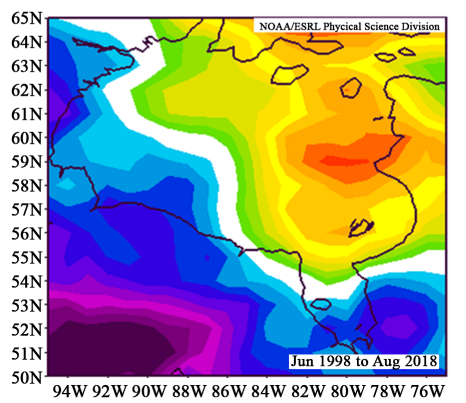

(c)

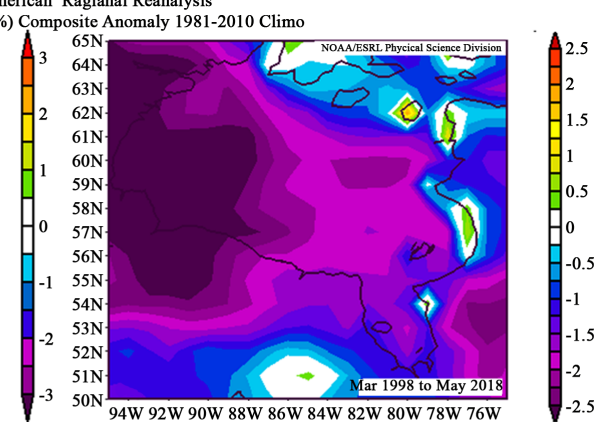

(b)

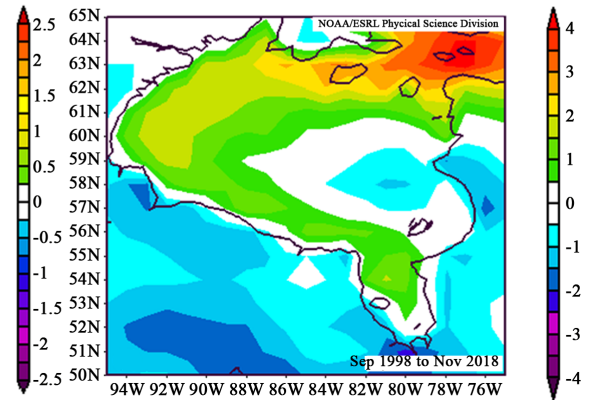

(d)

Figure 10. Seasonal anomaly map for low cloud area fraction from 1998-2018, departure from normal period for winter (a); spring (b); summer (c) and fall (d) for Hudson Bay.

whereas in some east area, it has been decreased $\sim 0.5-1.5 \%$. During fall seasonal time, there is a positive low-cloud response to reduction of sea ice, which explain that recent cloud changes causing to increase the Arctic warming and accelerating the sea ice decline (Eastman \& Warren, 2010).

\subsection{Wind Vector Anomaly at $1000 \mathrm{mb}$}

Figure 11 shows the $1000 \mathrm{mb}$ wind vector anomaly over the study area for winter (a), spring (b), summer (c) and fall (d). The anomaly maps for all seasons show the anti-cyclonic intensification mostly in the central areas. Whereas in the eastern outside boundary, the cyclonic curvature has been developed. This can be contributed to the accelerating low-level wind (see Figure 12) mostly over the areas with wind shear development. The anticyclonic circulation anomaly is contributed to the accelerating of the summer sea ice decreases (Ogi \& Rigor, 2013).

\subsection{Mean Sea Level Pressure Anomaly}

Mean sea level pressure anomaly map for wintertime is presented in Figure 12(a). This figure shows a decreased low pressure tough (decreasing from $50 \mathrm{~Pa}$ in the northeast to around $80 \mathrm{~Pa}$ in the east part of James Bay). This means the strengthening of the eastern trough associated with cyclonic circulation developing over the east part of Hudson Bay (see Figure 12(a)). This figure also displays that horizontal pressure gradient (pressure change with distance causing acceleration in momentum equation) over the eastern part of Hudson Bay. It is 

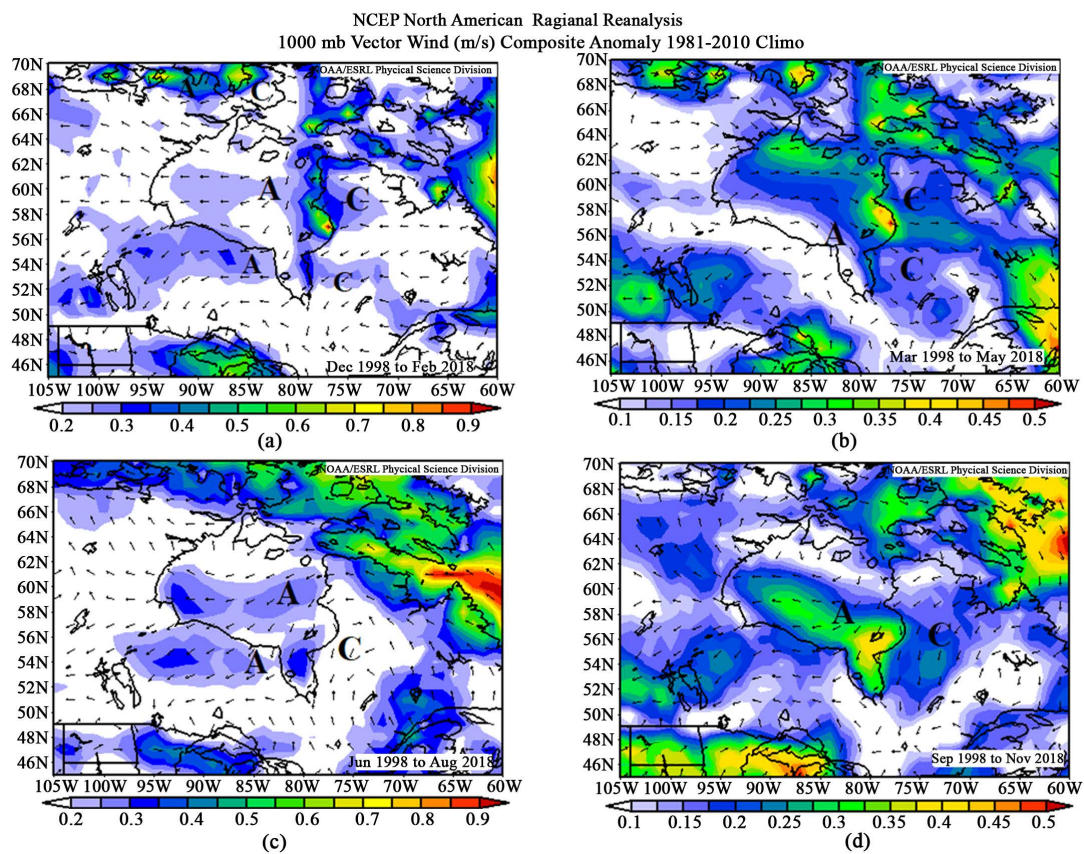

Figure 11. Seasonal anomaly map for $1000 \mathrm{mb}$ wind vector from 1998-2018, departure from normal period for winter (a); spring (b); summer (c) and fall (d) for Hudson Bay.

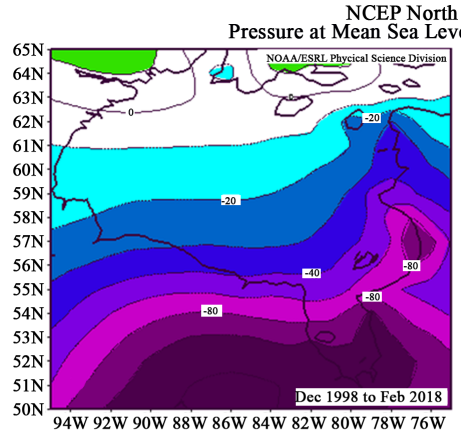

(a)

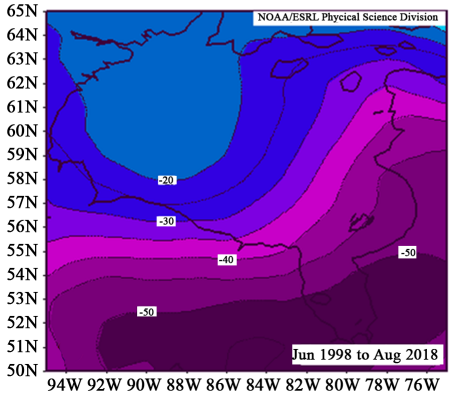

(c)
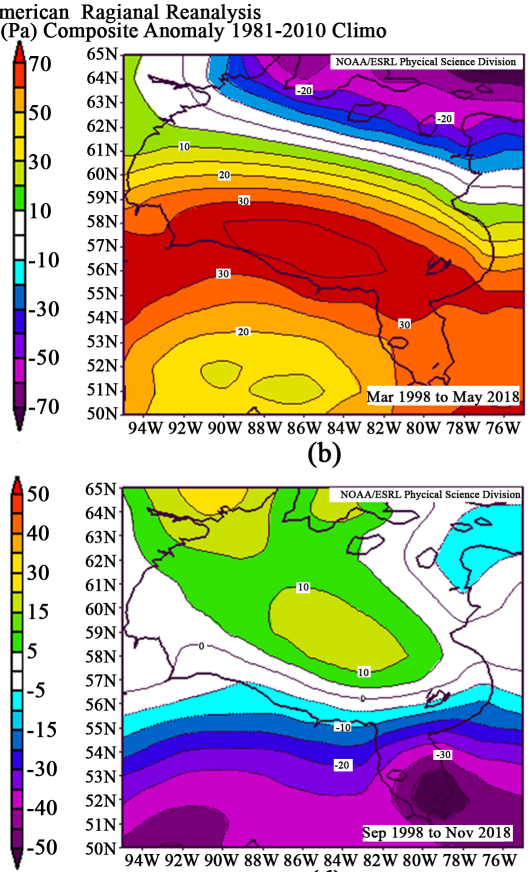

(b)

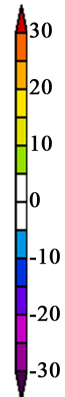

35
25
15
5
-5
-15
-25
-35

(d)

Figure 12. Seasonal anomaly map for mean sea level pressure from 1998-2018, departure from normal period for winter (a); spring (b); summer (c) and fall (d) for Hudson Bay.

notable that $10 \mathrm{~m}$ wind anomaly (Figure 13(a)) also confirms the increase of the wind speed (in the momentum equation the pressure gradient governs the wind velocity). Figure 12(b) is as same as Figure 12(a) but for spring anomaly time. This figure shows the decrease in pressure in the north-west and north parts 


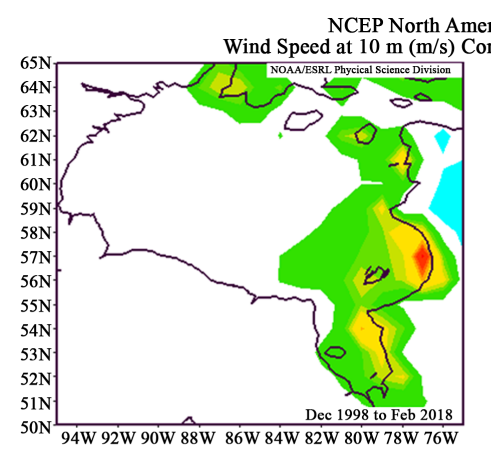

(a)

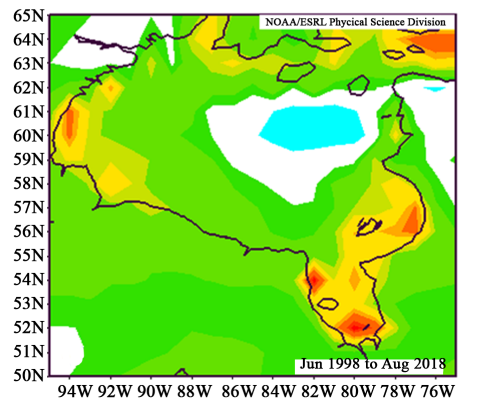

(c)

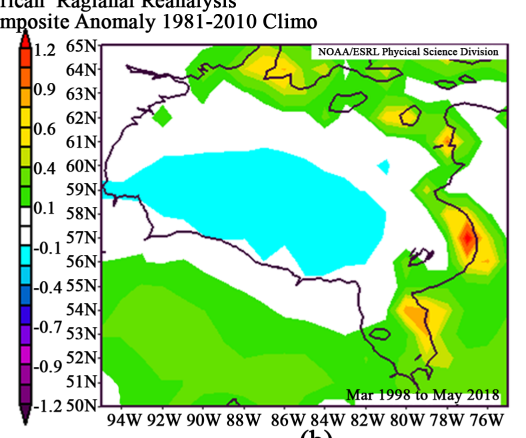

(b)

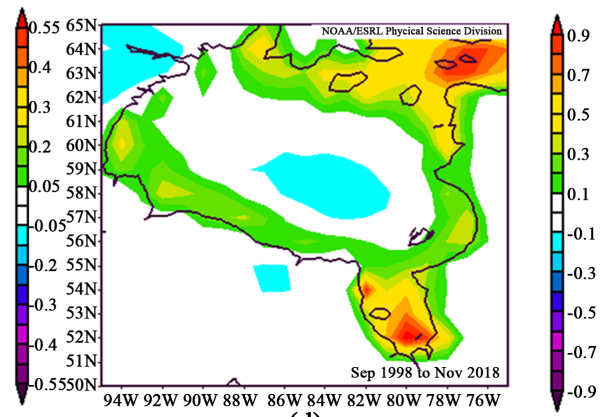

(d)

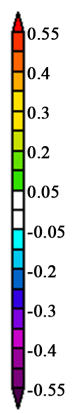

0.9
0.7
0.5
0.3
0.1
-0.1
-0.3
-0.5
-0.7
-0.9
Figure 13. Seasonal anomaly map for wind speed at $10 \mathrm{~m}$ from 1998-2018, departure from normal period for winter (a); spring (b); summer (c) and fall (d) for Hudson Bay.

along with the pressure increase in the west, central, south and east parts of Hudson Bay. It is remarkable that $10 \mathrm{~m}$ wind anomaly (Figure 13(b)) analysis shows the increase of the wind speed mostly in the north, northwest and eastern parts. Figure 12(c) is the same as Figure 12(a) but for summer anomaly time. This figure shows that the pressure has been decreased in most parts the study area, deepening the eastern trough from south-east to the north along with another trough (in the south-west of map outside of the Hudson Bay) from south to west boundary of Hudson Bay. This makes to increase the winds at $10 \mathrm{~m}$ (see Figure 12(c)). Figure 11(d) shows the mean sea level pressure anomaly map for fall. This figure shows considerable pressure gradient over James Bay (decreasing pressure around $30 \mathrm{~Pa}$ in the south and increasing the pressure around $10 \mathrm{~Pa}$ in the central part). Also, the pressure gradient has been formed between northeast and central parts causing wind speeding (see Figure 13(d)).

\subsection{Wind Speed Anomaly at $10 \mathrm{~m}$}

Figure 13(a) shows anomaly wind speed at $10 \mathrm{~m}$ in winter departure from normal time. The wind speed has been increased over the eastern boundary around $0.1-1.2 \mathrm{~m} \cdot \mathrm{s}^{-1}$ and in the north-west area at around $0.1-0.6 \mathrm{~m} \cdot \mathrm{s}^{-1}$. The maximum wind speed increase is around $1.2 \mathrm{~m} \cdot \mathrm{s}^{-1}$ in the eastern part in Umiujaq area. The wind speed increase has been occurring over the area with increasing pressure gradients associated with increasing of the contrast between cyclonic and anti-cyclonic and curvature developments. Figure 13(b) shows spring ano- 
maly wind speed at $10 \mathrm{~m}$ over the study area. The wind has been increased in the north-west, northeast, east, south-east and James Bay area. The wind speed has been increased from the lower value at $\sim 0.05 \mathrm{~m} \cdot \mathrm{s}^{-1}$ in the external isotach (lines on the weather maps connecting points where equal speeds winds) to the maximum amount in the core $\sim 0.55 \mathrm{~m} \cdot \mathrm{s}^{-1}$ in the eastern area near Umiujaq area. In the James Bay region, mostly in the eastern part, the maximum wind increase is at $\sim 0.3 \mathrm{~m} \cdot \mathrm{s}^{-1}$. Figure 13 (c) shows the anomaly wind speed at $10 \mathrm{~m}$ during summer periodic time over the study area. The most boundary parts of Hudson Bay in the north, west, south-west, east, southern part and James Bay has increased in $10 \mathrm{~m}$ wind speed because of the contrast between cyclonic and anti-cyclonic changes (see figure wind vector anomaly). The isotach lines are from $0.05 \mathrm{~m} \cdot \mathrm{s}^{-1}$ to the maximum value around $0.55 \mathrm{~m} \cdot \mathrm{s}^{-1}$ in the James Bay region (with significant changes in depression at $\sim 50 \mathrm{~Pa}$ and so having intense cyclonic intensification). There is no change or small decreasing in the central part with no significant change in pressure gradient. Figure 13(d) shows anomaly wind velocity at $10 \mathrm{~m}$ during fall. The boundaries of Hudson Bay have increased wind speed. The areas with no pressure gradient have no change in the wind. The increase in wind speed from the centre to the Hudson Bay boundaries has been increased from nearly $0.1 \mathrm{~m} \cdot \mathrm{s}^{-1}$ to at around $0.9 \mathrm{~m} \cdot \mathrm{s}^{-1}$ in the centre of isotach lines. But in the James Bay area, the low-level wind speed has been increased with the maximum at around $0.9 \mathrm{~m} \cdot \mathrm{s}^{-1}$ because of the pressure gradient between depression in the James Bay area $(35 \mathrm{~Pa})$ with an anticyclonic intensification area $(\sim 5-10 \mathrm{~Pa})$ in the south-east corner in the Figure 12(d). In the areas with no gradient, the wind has been decreased. Also, with the development of anticyclonic pattern, the wind has been decreased due to rather a stable condition.

\subsection{Anomaly of the Total Average Precipitation at Surface}

Figure 14(a) shows the total average precipitation anomaly during wintertime. This figure presents that the total average precipitation has been increased in the north, eastern boundaries and east of James Bay with the maximum amount in the east pat at around $0.55 \mathrm{Kg} / \mathrm{m}^{2}$. Figure 14 (b) shows the anomaly mean precipitation during springtime. The anomaly map shows no change or decrease in precipitation rates in most of Hudson Bay. Only in a small area in the south-west of James Bay has an increase at $\sim 0.1 \mathrm{Kg} / \mathrm{m}^{2}$. Figure 14 (c) shows the total average precipitation anomaly during summertime with mostly no change and an only small increase in the southern boundary. Figure 14(d) shows the same map as Figure 14(a) but for fall. The precipitation has been in the north-west, northeast, and south-east of Hudson Bay with the maximum at around $0.35 \mathrm{~kg} / \mathrm{m}^{2}$ in James Bay.

\subsection{Anomaly of the Downward Longwave Radiation at Surface}

Downward longwave radiation at the surface is a key component of the surface radiation budget and is closely related to surface temperature and is linked to the 


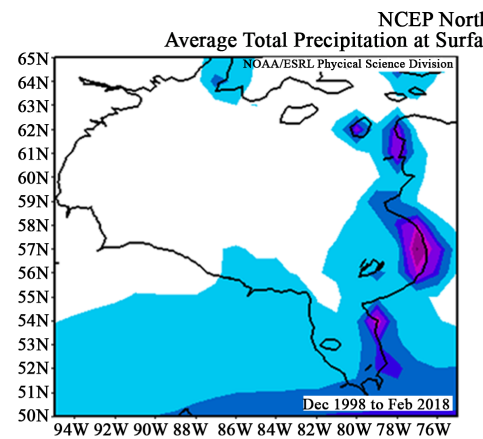

(a)

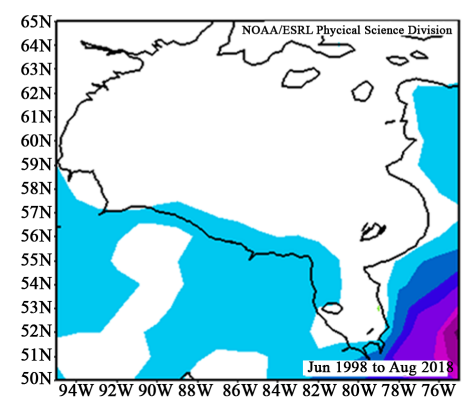

(c)

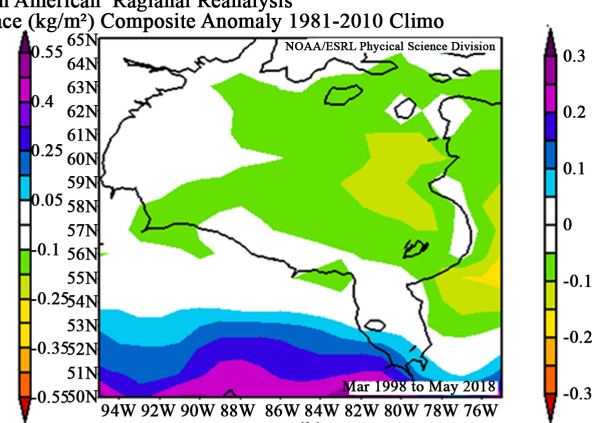

(b)

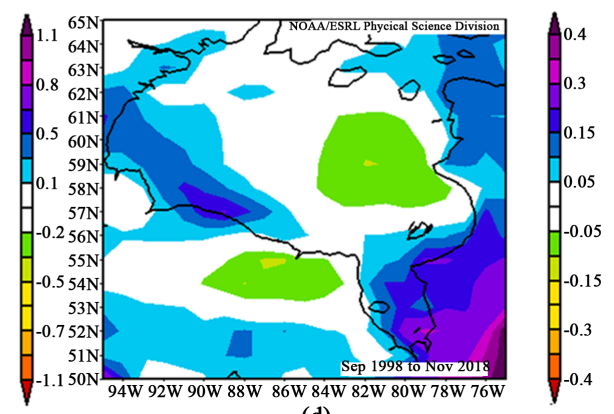

(d)

Figure 14. Seasonal anomaly map for total average precipitation at surface from 1998-2018, departure from normal period for winter (a); spring (b); summer (c) and fall (d) for Hudson Bay.

soil moisture and evapotranspiration. Also, the downward longwave radiation at the surface as one of the four (three other components include; the upward longwave radiation, the incoming solar radiation (insolation) and the reflected solar radiation) key components of the Earth's surface energy budget is a significant factor to consider on the oceanic and atmospheric circulations. The surface atmospheric downward longwave radiation explains the effects of the atmospheric greenhouse, which is related to atmospheric clouds, the water contents in the atmosphere, also the lower atmospheric temperature profiles (Kasting, 1988; Stephens \& Greenwald, 1991). With the absence of the clouds, it is largely depending on the lower atmospheric greenhouse gases density like water vapour and $\mathrm{CO}_{2}$ concentration (Kasting, 1988; Stephens \& Greenwald, 1991). The capability of these greenhouse gases in emitting longwave radiation, is a function of their temperature fourth power, as predicted by Stefan-Boltzmann law which is significantly depending on the global warming (Wild et al., 2008). In the cloudy conditions, it is also defined by the spatial and vertical distribution of clouds, in special the low clouds (Ma et al., 2014).

Figure 15 shows downward longwave anomaly radiation at the surface during winter (a), spring (b), summer (c) and fall (d). As the figure shows that downward radiation at the surface has been increased during all seasons mostly in fall and winter in all parts of Hudson Bay expect during spring which has no change or decrease in some parts (Figure 15(b)). This figure also shows the increase of the downward longwave radiation anomaly at surface mostly is in the in east, 
north, north-west boundaries of Hudson Bay. It seems in all figures the highest changes are corresponding to the regions with rather warmer surface (Figure 4). The excess in longwave radiation can be related to rather warmer surface and then can be balanced or cooling by increased evaporation (Figure 8). It seems these areas are corresponding to the regions with more increase in cloudiness (Figure 9 and Figure 10) and more moisture (Figure 6) available near the surface (see Figure 15).

\subsection{Anomaly Albedo at Surface}

Figure 16(a) shows winter albedo anomaly map departure from 1981-2010 (climatology normal period). Winter albedo has been decreased mostly in the eastern part of Hudson Bay around 3\% - 18\% ( 2.5 - 4.5 K) increase in $2 \mathrm{~m}$ air temperature and $\sim 3-4 \mathrm{~K}$ increase in $2 \mathrm{~m}$ dew point temperature). The comparison of this figure with the near-surface thermal structure $(2 \mathrm{~m}$ air temperature anomaly Figure 3) shows the rather warmer winter air mass accompanies which can decrease static stability, vertical motion increasing and cloud formation causing the increase in precipitation rate with the rather convective unstable condition. Figure 16(b) shows spring albedo anomaly time over the study area. During spring by the beginning of the melting progress, the albedo anomaly shows that the values have been decreased mostly in scattered parts in the boundary pars of Hudson Bay around 3\% - 18\% (1 - 1.6 K) increase in $2 \mathrm{~m}$ air temperature and $\sim 1-1.84 \mathrm{~K}$ increase in $2 \mathrm{~m}$ dew point temperature. The comparison of this figure with near-surface thermal structure $(2 \mathrm{~m}$ air temperature

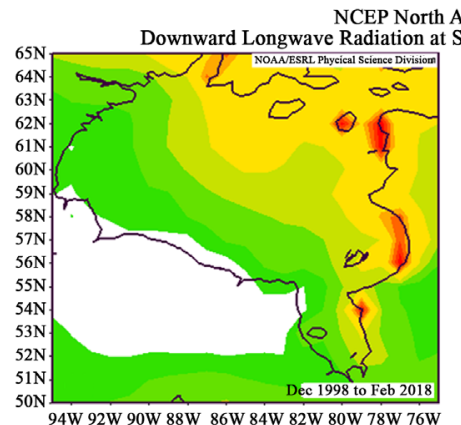

(a)

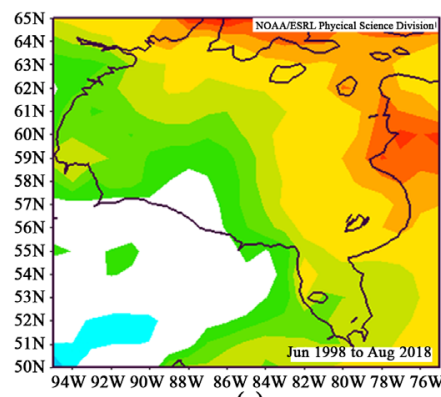

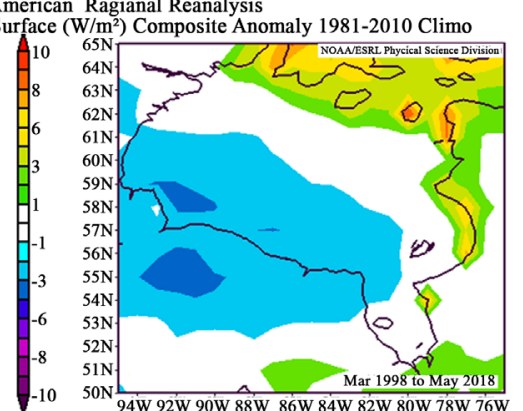

(b)

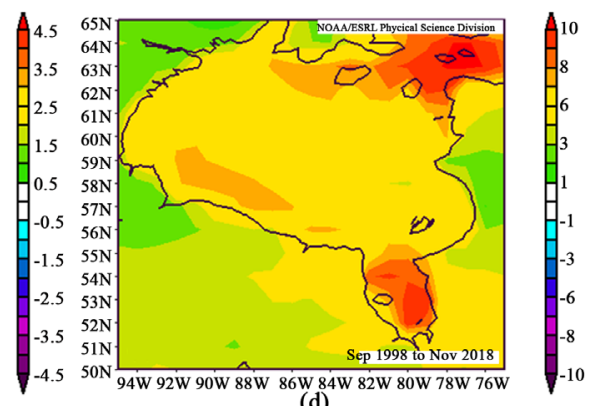

(d)

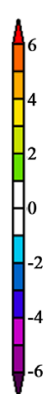

$A^{10}$
-6
-1
-1
-3
-6
-8
-10

Figure 15. Seasonal anomaly map for downward longwave anomaly radiation at surface from 1998-2018, departure from normal period for winter (a); spring (b); summer (c) and fall (d) for Hudson Bay. 


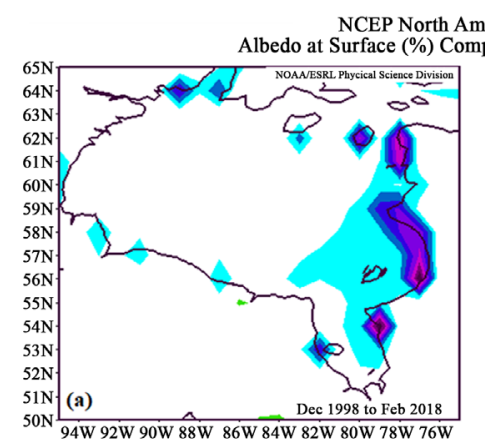

(a)

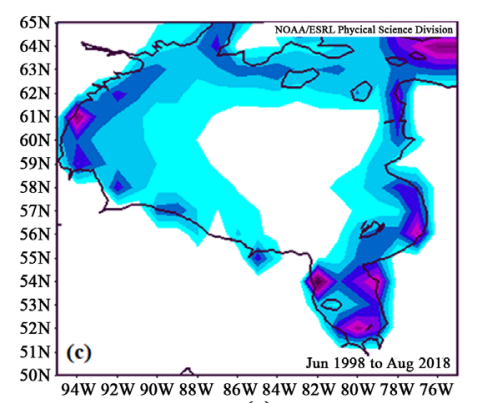

(c)

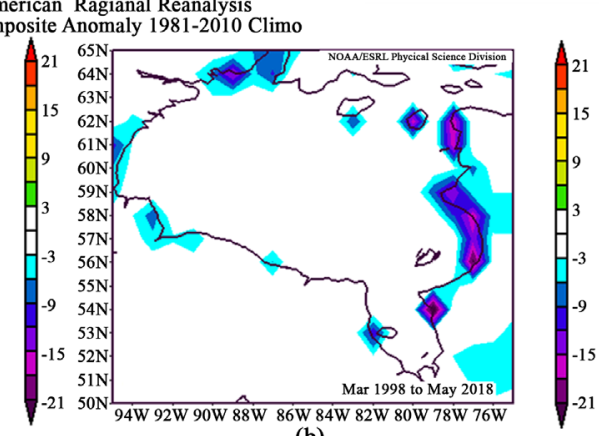

(b)

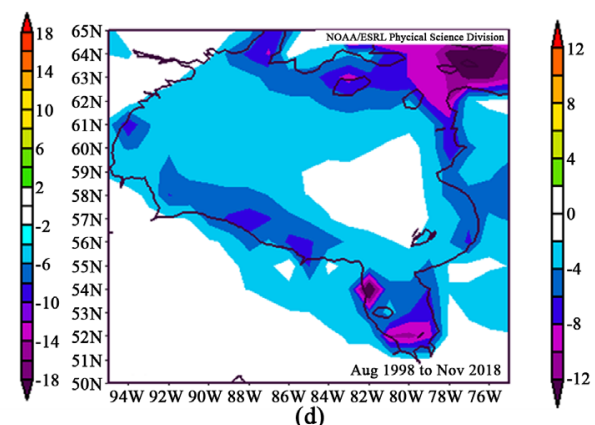

(d)

Figure 16. Seasonal anomaly map for surface albedo from 1998-2018, departure from normal period for winter (a); spring (b); summer (c) and fall (d) for Hudson Bay.

anomaly figure) shows the areas around the boundaries of Hudson Bay with the rather warmest isotherm anomaly values are nearly around the areas with decreasing of surface albedo. Figure 16(c) shows albedo anomaly during summer time. Except for the central part, mostly the boundaries areas of Hudson Bay have significant decreasing of albedo. Albedo values have been decreased from $2 \%-20 \%$ mostly in the boundary areas and the James Bay region. Albedo feedback is very considerable during summer time when there is less Arctic sea ice along with the highest solar radiation. Figure 16(d) shows fall albedo anomaly departure normal period. The most part of Hudson Bay has decreasing albedo except in the small area in the central part. Albedo values have been decreased from $2 \%$ to $12 \%$ mostly in the boundary area James Bay region. The comparison of this figure with near-surface thermal structure ( $2 \mathrm{~m}$ air temperature anomaly) shows the areas mostly over James Bay with the rather warmest isotherm anomaly values, nearly have the highest values of the surface albedo decreasing. The albedo decrease in fall is associated with late freezing up in Hudson Bay during the fall season.

\section{Seasonal T-Test and Regression Analysis}

The t-tests for atmospheric parameters such as temperature at $2 \mathrm{~m}$, low level cloud fraction, and surface albedo for mean values during all seasons from late 1998 to 2015 (as Figure 1 shows, this is as a sub anomaly periodic time) and their normal climatology mean values show the much smaller p-values rather than the significance level which was set at 0.05 . So, t-test shows a real difference 
during anomaly periodic time rather than the climatology normal mean time. The linear regression analysis of the seasonal anomalies for the low level clouds area fraction against temperature at $2 \mathrm{~m}$ (Figure 17) show the meaningful relationship between the increasing of low clouds with the increasing in temperature anomaly for all season $\left(\mathrm{R}_{\text {winter }}^{2}=0.46, \mathrm{R}_{\text {spring }}^{2}=0.73, \mathrm{R}_{\text {fall }}^{2}=0.51, \mathrm{n}=699\right.$, two-tail $\mathrm{t}$-test at $p$-value nearly zero) with positive slopes except during summer $\left(\mathrm{R}_{\text {summer }}^{2}\right.$ $=0.34, \mathrm{n}=699$, two-tail $\mathrm{t}$-test at $p$-value nearly zero) which shows the negative slope. The result shows that during spring there is a significant positive correlation between low clouds and $2 \mathrm{~m}$ air temperature rather than other seasons. Clouds impact the balance of the changes in albedo and surface temperature the Arctic during the spring whereas in other season they impact to increase cooling (Wang \& Key, 2003). Also, the low-level clouds have a warming consequence during all seasons except summer (Figure 10).

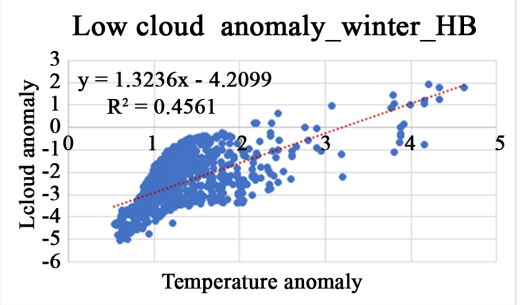

(a)

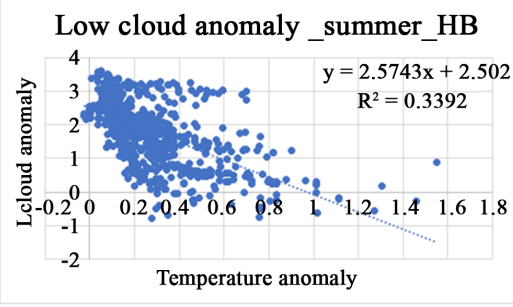

(c)

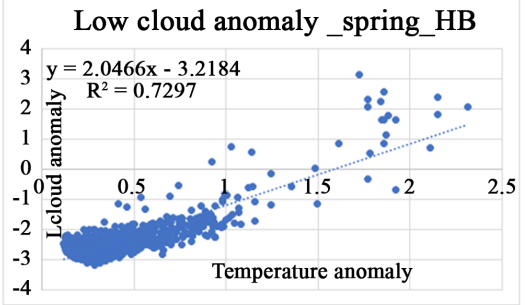

(b)

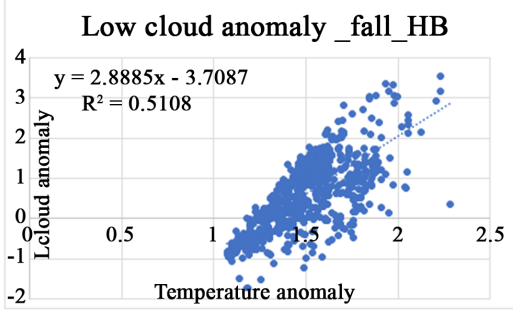

(d)

Figure 17. Seasonal anomaly map for air temperature at $2 \mathrm{~m}$ against anomaly of low cloud area fraction during 1998-2018, departure from normal period for winter (a); spring (b); summer (c) and fall (d) for Hudson Bay.

\section{Summary and Conclusions}

The high-resolution data set from NARR and NCEP has been examined to understand the recent two decades (1998-2018) seasonal changes in physical and meteorological key parameters in the Hudson Bay area. The long-term time series of the sea surface temperature and low-level air temperature from 1948 to 2018 have been studied. These results clearly have represented a warming shift for the Hudson Bay area from 1998. The surface and the low-level physical and atmospheric parameters such as sea surface temperature, albedo, air temperature, dewpoint temperature, specific humidity, relative humidity at $2 \mathrm{~m}$, accumulated evaporation at the surface along with clouds fraction in high- and low-level anomaly maps have been analysed. The results show important changes in atmospheric regional circulation patterns. The results show that dur- 
ing the anomaly period, the sea surface temperature has been increased mostly in north and east parts with the highest changes in winter. Near-surface air temperatures at $2 \mathrm{~m}$ and dew point temperature at $2 \mathrm{~m}$ have been increased in most parts of Hudson Bay with remarkable increases in the boundary regions in the north, east and south with the highest changes during wintertime. Additionally, the areas with the higher temperatures show the higher vertical motion (the figure does not present here) and then higher precipitation as well. The near-surface wind has been speeding over the area with the pressure gradients intensification accompanying to the wind contrast structure between cyclonic (connected with positive vorticity, figures are presented here) and anticyclonic (connected with negative vorticity) curvatures leading the wind shear. Anomaly wind at $10 \mathrm{~m}$ during fall and winter seasonal times have the greatest variations both in quantities and extension areas in Hudson Bay rather than summer and spring. This has good agreement with Ashtine et al. Also, the wind vector studying at different pressure levels has revealed zonal wind component weakening and meridional wind component increasing from 1998 in the Hudson Bay region (Fazel-Rastgar, 2019). The zonal winds weakening is associated with the reduction of the pole to mid-latitude temperature gradient producing the developed Arctic warming (Walsh, 2014).

The high-level clouds have been increased over the most parts of Hudson Bay with a higher rate during fall in James Bay and east part of Hudson Bay. The low-level clouds also have been increased over most parts of Hudson Bay with a higher rate during fall and summer.

The warm seasonal cloudiness Arctic, particularly with the low clouds can indicate the steady of the long summertime causing to summer sea ice reduction (Walsh et al., 2011). The low-level clouds are very important for cryosphere changes and the recent studies show the existence of the clouds cover over the sea ice tends to increase with the warming temperatures and sea ice reducing during all seasons excepting summer (Walsh et al., 2011). Studies show that during fall seasonal time there is a positive low-cloud response to reduction of sea ice, which explain that recent cloud changes causing to increase the Arctic warming and accelerating the sea ice decline (Eastman \& Warren, 2010). The cloudiness is one of the key factors in the Arctic climate because of the impact on the surface energy budget and cryosphere both in trends and interannual variations (Walsh et al., 2011). For example, the extreme Arctic Ocean sea ice retreat during summer is linked to the unusual clear skies (Kay et al., 2008).

Also, this research has revealed the downward longwave anomaly radiation at the surface has been increased during all seasons mostly in fall and winter in all parts of Hudson Bay. It seems that the highest changes are corresponding to the regions with rather warmer surface. Also, these areas are corresponding to the regions with more increase in cloudiness and more moisture available near the surface.

So, many of the changes in atmospheric and surface conditions in specific seasons have been quite dramatic over the anomaly period but they are often 
constrained to specific locales creating a large regional heterogeneity over Hudson Bay.

\section{Acknowledgements}

Thanks are given to NOAA/ESRL PSD, Physical Science Division, Boulder Colorado web page through http://www.esrl.noaa.gov/psd/ and Canadian census website through http://www12.statcan.gc.ca/census-recensement/2011/geo/bound-limit/bound-li mit-2011-eng.cfm. I would like to thank Prof. Bello and Prof. Higuchi for suggestion and comments.

\section{Conflicts of Interest}

The author declares no conflicts of interest regarding the publication of this paper.

\section{References}

Bintanja, R., \& Andry, O. (2017). Towards a Rain-Dominated Arctic. Nature Climate Change, 7, 263. https://doi.org/10.1038/nclimate3240

Bintanja, R., \& Krikken, F. (2016). Magnitude and Pattern of Arctic Warming Governed by the Seasonality of Radiative Forcing. Scientific Reports, 6, Article No. 38287. https://doi.org/10.1038/srep38287

Bintanja, R., \& Selten, F. M. (2014). Future Increases in Arctic Precipitation Linked to Local Evaporation and Sea-Ice Retreat. Nature, 509, 479. https://doi.org/10.1038/nature13259

Bintanja, R., \& Van der Linden, E. C. (2013). The Changing Seasonal Climate in the Arctic. Scientific Reports, 3, Article No. 1556. https://doi.org/10.1038/srep01556

Blunden, J., \& Arndt, D. S. (2012). State of the Climate in 2011. Bulletin of the American Meteorological Society, 93, S1-S282. https://doi.org/10.1175/2012BAMSStateoftheClimate.1

Chapman, W. L., \& Walsh, J. E. (1993). Recent Variations of Sea Ice and Air Temperature in High Latitudes. Bulletin of the American Meteorological Society, 74, 33-48. https://doi.org/10.1175/1520-0477(1993)074<0033:RVOSIA >2.0.CO;2

Comiso, J. C., Parkinson, C. L., Gersten, R., \& Stock, L. (2008). Accelerated Decline in the Arctic Sea Ice Cover. Geophysical Research Letters, 35, L01703. https://doi.org/10.1029/2007GL031972

Deser, C., \& Teng, H. (2008). Evolution of Arctic Sea Ice Concentration Trends and the Role of Atmospheric Circulation Forcing, 1979-2007. Geophysical Research Letters, 35, L02504. https://doi.org/10.1029/2007GL032023

Eastman, R., \& Warren, S. G. (2010). Interannual Variations of Arctic Cloud Types in Relation to Sea Ice. Journal of Climate, 23, 4216-4232. https://doi.org/10.1175/2010JCLI3492.1

Fazel-Rastgar, F. (2019). Hudson Bay Climate Change and Local Winter Wind Circulation. American Journal of Climate Change, 8, 544. https://doi.org/10.4236/ajcc.2019.84029

Fazel-Rastgar, F. (2020). The Evidence of Recent Canadian Arctic Climate Change. A Case Study, the Baffin Island. International Journal of Global Warming, 20, 165-185. 
https://doi.org/10.1504/IJGW.2020.10027062

Fazel-Rastgar, F. (in press a). Canadian Arctic Weather System Configuration Related to the Recent Sea Ice Decline and Heat-Wave of Summer 2019. International Journal of Global Warming.

Fazel-Rastgar, F. (in press b). Synoptic Climatological Approach Associated with Three Recent Summer Heatwaves in the Canadian Arctic. Journal of Water and Climate Change.

Flanner, M. G., Shell, K. M., Barlage, M., Perovich, D. K., \& Tschudi, M. A. (2011). Radiative Forcing and Albedo Feedback from the Northern Hemisphere Cryosphere between 1979 and 2008. Nature Geoscience, 4, 151. https://doi.org/10.1038/ngeo1062

Gough, W. A., Cornwell, A. R., \& Tsuji, L. J. (2004). Trends in Seasonal Sea Ice Duration in Southwestern Hudson Bay. Arctic, 57, 299-305. https://doi.org/10.14430/arctic507

Hansen, J., Sato, M., Ruedy, R., Lo, K., Lea, D. W., \& Medina-Elizade, M. (2006). Global Temperature Change. Proceedings of the National Academy of Sciences, 103, 14288-14293. https://doi.org/10.1073/pnas.0606291103

Hochheim, K. P., \& Barber, D. G. (2010). Atmospheric Forcing of Sea Ice in Hudson Bay during the Fall Period, 1980-2005. Journal of Geophysical Research: Oceans, 115, C05009. https://doi.org/10.1029/2009JC005334

Holland, M. M., \& Bitz, C. M. (2003). Polar Amplification of Climate Change in Coupled Models. Climate Dynamics, 21, 221-232. https://doi.org/10.1007/s00382-003-0332-6

Jeffers, S., Agnew, T. A., Alt, B. T., De Abreu, R., \& McCourt, S. (2001). Investigating the Anomalous Sea-Ice Conditions in the Canadian High Arctic (Queen Elizabeth Islands) during Summer 1998. Annals of Glaciology, 33, 507-512.

https://doi.org/10.3189/172756401781818761

Kalnay, E., Kanamitsu, M., Kistler, R., Collins, W., Deaven, D., Gandin, L., Iredell, M., Saha, S., White, G., Woollen, J., \& Zhu, Y. (1996). The NCEP/NCAR 40-Year Reanalysis Project. Bulletin of the American Meteorological Society, 77, 437-472. https://doi.org/10.1175/1520-0477(1996)077<0437:TNYRP>2.0.CO;2

Kasting, J. F. (1988). Runaway and Moist Greenhouse Atmospheres and the Evolution of Earth and Venus. Icarus, 74, 472-494. https://doi.org/10.1016/0019-1035(88)90116-9

Kay, J. E., \& Gettelman, A. (2009). Cloud Influence on and Response to Seasonal Arctic Sea Ice Loss. Journal of Geophysical Research: Atmospheres, 114, D18204. https://doi.org/10.1029/2009JD011773

Kay, J. E., L'Ecuyer, T., Gettelman, A., Stephens, G., \& O’Dell, C. (2008). The Contribution of Cloud and Radiation Anomalies to the 2007 Arctic Sea Ice Extent Minimum. Geophysical Research Letters, 35, L08503. https://doi.org/10.1029/2008GL033451

Ma, H., Xie, S., Klein, S. A., Williams, K. D., Boyle, J. S., Bony, S., Williamson, D. et al. (2014). On the Correspondence between Mean Forecast Errors and Climate Errors in CMIP5 Models. Journal of Climate, 27, 1781-1798. https://doi.org/10.1175/JCLI-D-13-00474.1

Manabe, S., \& Stouffer, R. J. (1980). Sensitivity of a Global Climate Model to an Increase of $\mathrm{CO}_{2}$ Concentration in the Atmosphere. Journal of Geophysical Research: Oceans, 85, 5529-5554. https://doi.org/10.1029/JC085iC10p05529

Mesinger, F., DiMego, G., Kalnay, E., Mitchell, K., Shafran, P. C., Ebisuzaki, W., Jovic, D., Woolle, J., Rogers, E., Berbery, E. H., \& Ek, M. B. (2006). North American Regional Reanalysis. Bulletin of the American Meteorological Society, 87, 343-360. https://doi.org/10.1175/BAMS-87-3-343

Ogi, M., \& Rigor, I. G. (2013). Trends in Arctic Sea Ice and the Role of Atmospheric Cir- 
culation. Atmospheric Science Letters, 14, 97-101. https://doi.org/10.1002/asl2.423

Overland, J. E., \& Wang, M. (2013). When Will the Summer Arctic Be Nearly Sea Ice Free? Geophysical Research Letters, 40, 2097-2101. https://doi.org/10.1002/grl.50316

Overland, J. E., Wang, M., Walsh, J. E., \& Stroeve, J. C. (2014). Future Arctic Climate Changes: Adaptation and Mitigation Time Scales. Earth's Future, 2, 68-74. https://doi.org/10.1002/2013EF000162

Parkinson, C. L. (2000a). Recent Trend Reversals in Arctic Sea Ice Extents: Possible Connections to the North Atlantic Oscillation. Polar Geography, 24, 1-12. https://doi.org/10.1080/10889370009377684

Parkinson, C. L. (2000b). Variability of Arctic Sea Ice: The View from Space, an 18-Year Record. Arctic, 53, 341-358. https://doi.org/10.14430/arctic866

Parkinson, C. L., \& Cavalieri, D. J. (2002). A 21 Year Record of Arctic Sea-Ice Extents and Their Regional, Seasonal and Monthly Variability and Trends. Annals of Glaciology, 34, 441-446. https://doi.org/10.3189/172756402781817725

Schweiger, A. J. (2004). Changes in Seasonal Cloud Cover over the Arctic Seas from Satellite and Surface Observations. Geophysical Research Letters, 31, L12207. https://doi.org/10.1029/2004GL020067

Schweiger, A., Lindsay, R., Zhang, J., Steele, M., Stern, H., \& Kwok, R. (2011). Uncertainty in Modeled Arctic Sea Ice Volume. Journal of Geophysical Research: Oceans, 116, C00D06. https://doi.org/10.1029/2011JC007084

Screen, J. A., Simmonds, I., \& Keay, K. (2011). Dramatic Interannual Changes of Perennial Arctic Sea Ice Linked to Abnormal Summer Storm Activity. Journal of Geophysical Research, 116, D15105. https://doi.org/10.1029/2011JD015847

Serreze, M. C., \& Barry, R. G. (2011). Processes and Impacts of Arctic Amplification: A Research Synthesis. Global and Planetary Change, 77, 85-96. https://doi.org/10.1016/j.gloplacha.2011.03.004

Serreze, M. C., \& Francis, J. A. (2006). The Arctic Amplification Debate. Climatic Change, 76, 241-264. https://doi.org/10.1007/s10584-005-9017-y

Serreze, M. C., Holland, M. M., \& Stroeve, J. (2007). Perspectives on the Arctic's Shrinking Sea-Ice Cover. Science, 315, 1533-1536. https://doi.org/10.1126/science.1139426

Stephens, G. L., \& Greenwald, T. J. (1991). The Earth's Radiation Budget and Its Relation to Atmospheric Hydrology: 1. Observations of the Clear Sky Greenhouse Effect. Journal of Geophysical Research, 96, 15311.

Walsh, J. E. (2014). Intensified Warming of the Arctic: Causes and Impacts on Middle Latitudes. Global and Planetary Change, 117, 52-63. https://doi.org/10.1016/j.gloplacha.2014.03.003

Walsh, J. E., Overland, J. E., Groisman, P. Y., \& Rudolf, B. (2011). Ongoing Climate Change in the Arctic. $A M B I O, 40,6-16$. https://doi.org/10.1007/s13280-011-0211-z

Wang, X., \& Key, J. R. (2003). Recent Trends in Arctic Surface, Cloud, and Radiation Properties from Space. Science, 299, 1725-1728. https://doi.org/10.1126/science.1078065

Wild, M., Grieser, J., \& Schär, C. (2008). Combined Surface Solar Brightening and Increasing Greenhouse Effect Support Recent Intensification of the Global Land-Based Hydrological Cycle. Geophysical Research Letters, 35, L17706. https://doi.org/10.1029/2008GL034842

Ye, H., Fetzer, E. J., Wong, S., Behrangi, A., Olsen, E. T., Cohen, J., Chen, L. et al. (2014). Impact of Increased Water Vapor on Precipitation Efficiency over Northern Eurasia. Geophysical Research Letters, 41, 2941-2947. https://doi.org/10.1002/2014GL059830 